\title{
Independence of parturition and mouse-killing by female rats'
}

\author{
RONALD BAENNINGER, Temple Uni- \\ versity, Philadelphia, Pa. 19122
}

Responses of female rats toward mice were unaffected by gestation, lactation, parturition, and caring for litters. Mousekilling mothers continued to do so, in several instances killing their own pups, while nonkillers never began to kill mice and showed instead maternal responses toward them. Both killer and nonkiller females showed normal maternal responses toward their own litters.

In his original paper on the mouse-killing response shown by some rats, Karli (1956) investigated the possibility that processes associated with giving birth could affect development of mouse-killing by female laboratory rats. Rats which did not kill mice prior to gestation, lactation, and parturition did not begin to do so following these events; this was true even though some mice actively interfered with normal maternal care by pushing neonatal rats out of their nest, occasionally eating them, and in the case of a pregnant female mouse, retrieving the rat pups to her own nest. None of these responses by mice interfered with the strong maternal behavior shown by the rat toward the mouse, nor did they induce mousekilling or defense of the young rats by their mother.

A still-unanswered question is whether gestation, lactation, and parturition have any effect on mouse-killing by female rats which were experienced killers before they became pregnant. Maternal behavior toward her rat pups is a strong response in normal female laboratory rats. It is conceivable that stimulus generalization might occur in one of two ways. Mouse-killing rats might fail to kill mice in the presence of a litter of rat pups and instead show maternal behavior toward a mouse by retrieving and crouching over it. Karli found that such responses are typically shown by nonkiller females soon after the onset of lactation, just prior to birth of her litter. On the other hand, mouse-killing is a strong response in experienced killers, and presence of a mouse could result in attacks not only on the mouse but on rat pups as well. The killer female, when presented with a mouse while with her litter, may show one or more of four responses: retrieving of mice, retrieving of rats pups, killing of rat pups, and killing of mice. Which of these would be shown was the question in this experiment.

\section{METHOD}

Subjects were 31 primiparous female, Long-Evans rats from a breeding colony maintained by the E. Of these, 13 had killed three mice in less than $1 \mathrm{~h}$ prior to mating, while 18 had failed to kill the three mice presented to them. Each of the rats was placed with a male killer rat for 2 weeks, and was subsequently placed in an isolation cage with nesting material, food, and water. Beginning on the day after isolation each rat was presented with one mouse daily for a maximum of $1 \mathrm{~h}$; if killed, the mouse was removed within $30 \mathrm{sec}$. This procedure was continued for 12 days post partum. At 21 days of age the litters were weaned; mothers were again tested for mouse-killing after removal of the litters.

\section{RESULTS}

Table 1 shows the main results. Gestation, lactation, parturition, and weaning had no effect on mouse-killing, as indicated by McNemar's test for significance of changes $\left(\chi^{2}=0.86, \quad d f=1, p>.05\right)$. Typically, nonkillers did not begin to kill mice and killers did not stop killing mice as a consequence of the neural and endocrine events associated with birth. In the one case where a killer stopped killing she had been a slow killer prior to mating and failed to kill 8 out of 10 mice prior to birth, after which she never killed again. The nonkiller which began to kill did so only 2 days after the birth of her litter, but killed mice vigorously thereafter. No changes in the behavior of any other $S$ toward mice occurred during any test.

Without exception, Ss which did not kill after birth showed maternal responses toward each mouse presented to them. They retrieved mice vigorously, during which mice often vigorously resisted and uttered distress vocalizations. By the end of $1 \mathrm{~h}$, the mouse was usually found in the nest among

Table 1

Number of Female Rats Consistently Responding Toward Mice as Indicated

\begin{tabular}{|c|c|c|c|}
\hline & & \multicolumn{2}{|c|}{$\begin{array}{c}\text { During Gestation } \\
\text { and Post-Partum } \\
\text { Tests }\end{array}$} \\
\hline & & Kill & Nonkill \\
\hline During 3 Tests & Kill & 12 & 1 \\
\hline Prior to Mating & Nonkill & 1 & 17 \\
\hline
\end{tabular}

the rat pups underneath the female rat. This pattern of interaction was also shown by all nonkillers toward mice presented prior to birth.

Maternal responses were never observed in killers; they always attacked and killed mice within $1 \mathrm{~min}$ after their presentation. of the 13 post-partum killers, 5 also occasionally attacked or killed their own rat pups after the mouse was presented. In most cases these attacks appeared accidental, occurring while the rat was leaping toward the mouse, or pushing pups out of the way to reach the mouse. In three instances the attacks appeared deliberate, with repeated bites directed at the back of the rat pup. A small percentage of adult rats kill mice and weanling rat pups indiscriminately (Myer, 1964). Two of these killers and three nonkillers ate their litters; this is, of course, a not uncommon occurrence among laboratory rats when the nest is disturbed.

\section{DISCUSSION}

It seems clear that the profound neuroendocrine changes associated with gestation, lactation, and parturition have little or no effect on the mouse-killing response, neither initiating it nor suppressing it. Rats which do not kill mice show generalization of maternal responses to them and do not chase or attack mice which approach their litters, while mouse-killing rats always attack and kill mice, occasionally showing some generalization of these responses to their own pups. Killers seem to be just as good mothers as nonkillers (as judged by litter survival).

Attacks by mice on young rats were not seen in this experiment. Karli let mice live with rats, while mice were present only during $1 \cdot h$ trials in the present experiment. From an evolutionary standpoint nonkiller females which allow another species to passively or actively interfere with their young would seem to be as maladaptive as killer females which kill their own young in the course of attacking an intruder. The conclusion seems clear on the basis of these and Karli's data that mouse-killing and maternal responses of female laboratory rats are independent.

\section{REFERENCES}

KARLI, P. The Norway rat's killing responses to the white mouse: An experimental analysis. Behaviour, 1956, 10, 81-103.

MYER, J.S. Stimulus control of mouse killing rats Journal of Comparative \& Physiological Psychology, 1964, 58, 112-117.

$$
\text { NOTE }
$$

1. This experiment was supported by Grant MH 13501-01 from the National Institute of Mental Health and by a grant-in-aid from Temple University. 